\title{
ETNOLICHENOLOGY OF OLD MENS BEARD (Usnea spp) AT PRIANGAN
}

\author{
lin Supartinah Noer ${ }^{1}$, Betty Mayawatie ${ }^{2}$, Leni Maryani², Jujun Juanda², \\ and Anggit Manganti ${ }^{2}$
}

\author{
${ }^{1}$ Corresponding author; lin Supartinah Noer, Department of Biology, \\ Faculty of Mathematics and Natural Sciences, University of Padjadjaran, Bandung, Indonesia. Tel.: +62-21- \\ 64713850; fax: +62-21-63711948; \\ ${ }^{2}$ Department of Biology, Faculty of Mathematics and Natural Sciences, \\ University of Padjadjaran, Bandung, Indonesia. \\ e-mail: iiinsnoer@unpad.ac.id or insnoer@yahoo.co.id
}

\begin{abstract}
Usnea has been used for a long time in Indonesia for traditional medicine and crude material for jamu. The study of taxonomy and local knowledge at Priangan are less information. The research was conducted between March 2011-April 2012. The aim of this research was to explore the local knowledge of species Usnea conducted by emic and ethic approaches. The specimens collection was done by survey along the pine forest at Bandung, Sumedang, Garut, Ciamis and Tasikmalaya in Priangan areas. The specimens were analysis morphological, anatomy and chemical. The etnolichenology study was done by descriptive qualitative, survey and interview also observation participative at Gunung Gelap Village and Kamojang area of Garut Regency and Cibunar village,Sumedang Regency in West Java. The interview was done with key informants. The taxonomical study found the 11 species of Beard lichens found in pine forest at Priangan, belong to 3 subgenus. They are subgenus Dilichousnea, consist of Usnea filipendula, U. hirta, U. Iongisima and U. trichodea. Subgenus Eumitra consist of U.baileyi and U. ceratina. Subgenus Usnea consist of U. cornuta, $U$. flexilis, Usnea. flexuosa, U. florida and U.glabra. The dominant species growing on pine in different location are $U$. baileyi and $U$. flexilis. They have thalli colour dark green, yellow-green, pale green and reddish brown. Thallus branching is dichotomous in all species with difference in the thickness form the isotomic or anisotomic dichotomous types. Species Usnea is fructicose with habits erect type or subpendent type or pendent type. The lichenic acid contain in Usnea species are different and dominant by usnic acid and protocetoric acid. The stictic acid only found in U.flexuosa. The result of interview known that Usnea was called janggot kai by the Sundanese. People grouping the Usnea based on colour, growth pattern and surface of thallus, so known "Janggot kai hejo, janggot kai koneng, janggot kai rubak, janggot kai ngaruntuy, janggot kai kesrak and janggot kai lemes". Mostly the people used Usnea as raru for preservative nira, medicine and spices. The Sudanese used Usnea in formula oj jamu or ubar kampong to treat mouth ulcer, dysentery, catch a cold, skin eruption, stiff, menstruation painful, hemorrhoids, child birth ease and in making mahinum (jamu for mother after utter) and used as face powder of noble woman.
\end{abstract}

Keywords: Usnea, local knowledge, raru, ubar kampong.

ISSN 2413-0877 @ 2015 The Authors.

Published by KnowledgeE Publishing Services This is an open access article under the CC BY-NC-ND license (http://creativecommons.org/licenses/by-nc-nd/4.0)

Selection and Peer-review under responsibility of the 3rd ICBS-2013

Doi http://dx.doi.org/10.18502/kls.v2i1.162 